УДК 377.014 .5

DOI:

Інна Ромащенко, кандидат педагогічних наук, доцент кафедри іноземних мов Таврійського національного університету імені В.І. Вернадського

Маргарита Романова, директор Київського коледжу міського господарства Таврійського національного університету імені В.І. Вернадського

\title{
СУЧАСНІ АСПЕКТИ РОЗВИТКУ КОЛЕДЖУ ЯК ЗАКЛАДУ ФАХОВОЇ ПЕРЕДВИЩОЇ ОСВІТИ
}

У статті розглянуті питання розвитку і планування діяльності коледжуяк закладу фахової передвищої освіти на основі застосування стратегічного менеджменту.

Проаналізовані підходи до вибору стратегї розвитку закладу освіти, моделі управління та сутність найбільш характерних прочесів, щу потребують керування. Авторами досліджено можливі моделі стратегічної поведінки, иілі, фактори інтересів стейкхолдерів та фактори їхнього впливу на діяльність закладу освіти, узагальнені підходи до вибору цільових показників діяльності та розвитку закладу фахової передвищьї освіти.

Ключові слова: стратегія; заклад фахової передвищої освіти; стейкхолдери; модель поведінки; иільові показники.

Рис. 1. Табл. 3. Лім. 24.

Inna Romashchenko, Ph.D.(Pedagogy), Associate Professor of the Foreign Languages Department, Tauriya Volodymyr Vernadskiy National University Marharita Romanova, Head of Kyiv College of Municipal Service Tauriya Volodymyr Ivanovych Vernadskiy National University

\section{MODERN WAYS OF COLLEGE DEVELOPMENT AS THE PROFESSOINAL INSTITUTION OF PREHIGHER EDUCATION}

Authors research the questions of college development and planning that are based on strategic management from the point of view of the Professional institution of pre-higher education. The researches gave practical help to find the best way to reorganize college management in modern time of reforms in education and find ways to satisfy the state requirements and customers needs. They show the possibility to find solutions for many important questions in order to overcome problems that every college has at present not only from pedagogical point of view but for all components of college management problem solving.

The article gives the observation and analysis of effective approaches to strategic planning of further college development in current times of higher education changes and reforms. The strategic set of goals, essential conditions and management trends of college activity as a professional institution of pre-higher education are clearly defined by authors. The researchers gave the focus on new legislative requirements to colleges and their influence on colleges perspectives in the nearest future.

The approaches to define the best strategy for further educational establishment development, its management model and main activity features are analyzed. The authors outlined possible strategic activity models, goals, directions of implementing new approaches, the main perspectives of development, pursuing the stakeholders common interests and their abilities to influence on the achievement of the results that college has to get as the Professional Institution of Pre-higher Education after having generalized and summarizing indicators for strategic planning college development and effective cooperation with all participants of the educational process. Authors underlined the strategic visions of college competitiveness in education system of Ukraine on the base of strategic management as a unique resource of training professional competitive specialists for market economy of our country.

Keywords: strategy; professional institution of pre-higher education; stakeholders; activity models; goal indicators.

П

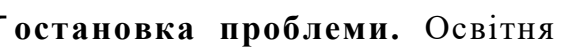
галузь нашої країни сьогодні знаходиться у стані модернізації та реформування. Це пов'язано із тим, що заклади вищої освіти поки що не надають адекватної відповіді запитам ринку праці та вимогам науковотехнічного прогресу. Наслідком цього $\epsilon$ збільшення дисбалансу між потребами зовнішнього середовища іздатністю закладів вищої освіти їх задовольняти. 3 одного боку, зростають вимоги до рівня кваліфікації працівників без вищої освіти. 3 іншого боку, реформування підготовки за освітньо-кваліфікаційним рівнем молодшого спеціаліста, простір розумової праці, яка може бути ефективно виконана працівниками без фундаментальної вищої освіти, постійно звужуеться. 
Згідно Закону України “Про фахову передвищу освіту” з 2020 року підготовка фахівців за освітньно-кваліфікаційним рівнем “молодший спеціаліст" та саме поняття "молодший спеціаліст” буде виведено з системи вищої освіти. Натомість запроваджується новий складник “Фахова передвища освіта" [21]. Зміна умов і правил функціонування коледжів, як закладів фахової передвищої освіти, вимагають сучасних підходів до управління розвитком і діяльністю, що своєю чергою, передбачає розробку стратегії і планів дій.

Аналіз останніх досліджень і публікацій. Проблеми удосконалення теорії управління висвітлені в роботах провідних вітчизняних і закордонних вчених, зокрема, В. Андрущенка, О. Віханського, В. Гейця, С. Клепко, М. Клименюка, В. Кременя, Р. Клейнера, В. Лугового, О. Марухленко, С. Натрошвілі, В. Радкевича, С. Сисоєвої та ін. Розгяд питань управління закладами освіти, заснованого на засадах стратегічного менеджменту детально розкриті в наукових роботах дослівників Б. Гершунського, Л. Карамушки, О. Пометун, І. Качарян, О. Пометун, М. Поташника та ін.

Метою статті $є$ розгляд підходів до вибору стратегії розвитку освітнього закладу, моделі його управління та сутності найбільш характерних процесів, що потребують керування, визначення та узагальнення підходів до встановлення цільових показників під час планування розвитку коледжу як закладу фахової передвищої освіти.

Виклад основного матеріалу. Реформування освітньої сфери спрямовано на створення системи, яка сприяє соціально-економічному розвитку нашої держави і дає змогу збалансувати у структурі працездатного населення надлишок спеціалістів 3 вищою освітою і дефіцит кваліфікованих працівників без повної вищої освіти.

Особливі вимоги висуваються до коледжів, які надають освіту вище загальної середньої. 3 огляду на реформування системи вищої освіти України з 2020 року Коледжі можуть залишитись у системі вищої освіти або розпочати працювати як заклади фахової передвищої освіти, надаючи студентам фахову передвищу освіту за освітнім ступенем “фаховий молодший бакалавр”, тому 3 2020 року коледжі більше не будуть здійснювати набір вступників на навчання за освітньокваліфікаційним рівнем молодшого спеціаліста, як це передбачено Законом України "Про фахову передвищу освіту" [5].

Таким чином, перед закладами освіти, які здійснюють підготовку молодших спеціалістів (вищі навчальні заклади I-II рівнів акредитаціі), постала задача переосмислення своєї діяльність та позиціонування в системі освіти України, визначення шляхів для подальшого розвитку 3 урахуванням власного бачення та вимог національного законодавства

У зв'язку із цим, коледжам, як закладам фахової передвищої освіти, у відповідності до вимог законодавства країни, важливо визначати стратегію подальшого розвитку і управління закладом освіти.

Коледж, як заклад освіти, порівняно 3 виробничими підприємствами, має свої особливості системи управління $[3,12]$. Розглядаючи освітній заклад із позицій практики і теорії менеджменту, науковці вважають, що як організація він ще недостатньо вивчений, а тому це не дає можливості базуватися на існуючі стандарти і методи управління при визначенні стратегії їхньої діяльності [18]. Разом iз тим, у наукових роботах підкреслено, що дієвим інструментом управління розвитком організації $є$ планування на засадах стратегічного менеджменту.

Основними складовими діяльності коледжу, як закладу фахової передвищої освіти, є i залишається освітній, консультаційний, навчальнометодичний освітній, виховний процес. У відповідності до вимог Закону “Про фахову передвищу освіту” коледж вибудовує стратегію свого розвитку, визначаючи місію, політику, враховує місце і значення кожного з названих процесів, розраховує і визначає обсяги необхідних ресурсів, що забезпечують ці процеси, зосереджує особливу увагу на питаннях кадрового забезпечення та якості надання освітньої послуги.

Головною метою такого підходу до планування розвитку і діяльності коледжу $є$ формування потенціалу майбутнього успіху організації для перетворення закладу у стійку, здатну до саморозвитку систему, що буде активно взаємодіяти із зовнішнім середовищем.

Дослідження наукових джерел свідчать про те, що коледжі, як заклади вищої, а тепер - і фахової передвищої освіти, в залежності від відомчої підпорядкованості та форми власності, можуть мати певні особливості управління процесами, в тому числі - економічними.

Науковці М. Клименюк, І. Качарян, О. Бевзін, ін. вважають, що кожен із названих вище процесів може розглядатися як виробничий, однак учені схиляються до думки, що освітній навчальний процес слід відносити до процесів надання послуг, які своєю чергою є складовими економічних процесів [9; 10].Усі економічні процеси у коледжі можна поділити на зовнішні клієнтські, управлінські та допоміжні.

Як підкреслено в наукових роботах дослідників, 
СУЧАСНІ АСПЕКТИ РОЗВИТКУ КОЛЕДЖУ ЯК ЗАКЛАДУ ФАХОВОЇ ПЕРЕДВИЩОЇ ОСВІТИ

\begin{tabular}{|c|c|c|}
\hline \hline $\begin{array}{c}\text { Отримання } \\
\text { ресурсів із зовнішнього } \\
\text { середовища }\end{array}$ & $\begin{array}{c}\text { Перетворення } \\
\text { ресурсів у продукт }\end{array}$ & $\begin{array}{c}\text { Передача } \\
\text { продукту у } \\
\text { (вхід) }\end{array}$ \\
& & зовнішнє середовище \\
(перетворення) & (вихід) \\
\hline
\end{tabular}

Рис. 1. Процес взаємодії організації з зовнішнім середовищем

система управління освітнім закладом, коледж це елемент системи освіти, тому особливості управління економічними процесами в ньому мають тісний зв'язок із особливостями всієї освітньої системи. Окрім того, в сучасних дослідженнях значна увага приділена розгляду сфери освіти як багаторівневої маркетингової системи [9]. Такий підхід дає змогу розглядати коледж як ринкову структуру, яка має свій товар - освітню послугу, виробника, споживача.

Саме тому, розглядаючи особливості управління коледжем важливо зосередити увагу на виборі моделі управління і визначити сутність найбільш характерних процесів, що потребують керування в ній.

Забезпечення розвитку освітнього процесу передбачає обов'язкову наявність предметів праці, приміщень, персоналу, технічних засобів навчання, навчально-методичних матеріалів, тощо. Окрім того, враховуючи мету діяльності закладу фахової передвищої освіти, - підготовка фахівців, які відповідають запитам ринку праці, необхідно розглядати і процеси якості та ефективності освітньої діяльності.

3 огляду на те, що заклад фахової передвищої освіти ми розглядаємо як ринкову структуру, то початком реалізації процесу стратегічного управління ним слід вважати “аналіз і прогнозування ринкового середовища організації”, який забезпечує керівництво інформацією, дозволяє вирішити групу проблем, пов'язаних із розвитком організаціі, і $є$ основою для розробки цілей, місії та стратегічних рішень [3; 11; 13].

Однією 3 ключових ролей будь-якого управління $є$ підтримка балансу у взаємодії організації із зовнішнім середовищем. Кожна організація залучена в три процеси (рис. 1.):

Управління покликане забезпечувати баланс між “входом” і “виходом”. Як тільки в організації порушується цей баланс, вона перестає ефективно функціонувати.

Сучасний ринок різко збільшив значення процесу виходу в підтримці цього балансу. Це знаходить відображення в тому, що в структурі стратегічного управління першим блоком $є$ блок аналізу середовища.

Аналіз середовища передбачає вивчення трьох iii складових: макрооточення, безпосереднього оточення, внутрішнього середовища організації.

Особливість сфери освіти полягає в тому, що вона має широкі, стійкі та сильні зворотні зв'язки зі своїм макросередовищем, оскільки формує цілі покоління фахівців, які в своїй подальшій діяльності починають визначати зміни цього середовища.

Аналіз макрооточення передбачає вивчення економічних, правових, політичних, соціальних, технологічних компонентів, що дозволяє коледжу розкрити тенденції, які характерні для зміни стану окремих важливих факторів (ресурсів), і допомагає визначити тенденції розвитку цих чинників, щоб передбачити, які загрози можуть очікувати організацію i, які можливості можуть відкритися перед нею в майбутньому.

Так, наприклад, важливим ресурсом коледжу $\epsilon$ абітурієнт. 3 огляду на демографічні показники, відтік молоді для здобуття освіти за кордоном, в країні буде існувати стан “демографічної ями“, що впливатиме на зниження кількісті абітурієнтів (табл. 1.).

Це означає, що при визначенні стратегії розвитку і управління заклад фахової передвищої освіти має враховувати показник цього важливого ресурсу для збереження позицій на ринку освітніх послуг.

Вивчення безпосереднього оточення організації спрямоване на аналіз стану тих складових зовнішнього середовища, з якими організація знаходиться в безпосередній взаємодії (табл. 2).

Основними суб'єктами взаємодії на ринку освітніх послуг є раціональні індивіди (абітурієнт - студент - випускник ) молодий спеціаліст), які намагаються максимізувати свої доходи за весь період життєвого циклу. Заклади фахової передвищої освіти покликані здійснювати якісну підготовку фахівців. Роботодавці (організації різних правових форм і сфер діяльності) мають потребу в кваліфікованій робочій силі, держава (в особі державних органів управління) як регулятор взаємодії [15].

Однак, поведінку суб'єктів на ринку освіти не можна визначити лише як “раціональну”, оскільки процесу рівноваги між попитом і пропозицією перешкоджає значний часовий “лаг” в дії ринкових регуляторів, а ринкова економічна 
Таблиця 1.

Показники прийому - випуску студентів до закладів вищої освіти України 2015- 2018 рр. (на початок навчального року)

\begin{tabular}{|c|c|c|c|c|c|c|}
\hline & \multicolumn{2}{|c|}{$\begin{array}{l}\text { Кількість осіб, прийнятих на } \\
\text { навчання до } 3 \mathrm{BO}^{4} \text {, тис. осіб }\end{array}$} & \multicolumn{2}{|c|}{$\begin{array}{l}\text { Кількість осіб, випущених із } \\
3 \mathrm{BO}^{5} \text {, тис. осіб }\end{array}$} & \multirow{2}{*}{$\begin{array}{l}\text { Кількість } \\
\text { аспірантів, } \\
\text { осіб }^{6}\end{array}$} & \multirow{2}{*}{$\begin{array}{l}\text { Кількість } \\
\text { докторантів, } \\
\text { осіб }^{6}\end{array}$} \\
\hline & $\begin{array}{l}\text { коледжі, } \\
\text { технікуми, } \\
\text { училища }\end{array}$ & $\begin{array}{l}\text { університети, } \\
\text { академії, } \\
\text { інститути }^{3}\end{array}$ & $\begin{array}{l}\text { коледжі, } \\
\text { технікуми, } \\
\text { училища }^{2}\end{array}$ & $\begin{array}{l}\text { університети, } \\
\text { академії, } \\
\text { інститути }^{3}\end{array}$ & & \\
\hline $\mathbf{2 0 1 5}^{1}$ & 63,2 & 259,9 & 73,4 & 374,0 & 28487 & 1821 \\
\hline $2016^{1}$ & 60,6 & 253,2 & 68,0 & 318,7 & 25963 & 1792 \\
\hline $2017^{1}$ & 59,1 & 264,4 & 61,2 & 359,9 & 24786 & 1646 \\
\hline $\mathbf{2 0 1 8}^{1}$ & 53,5 & 256,8 & 55,5 & 357,4 & 22829 & 1145 \\
\hline
\end{tabular}

${ }^{1}$ Без урахування тимчасово окупованої території Автономної Республіки Крим, м. Севастополя та частини тимчасово окупованих територій у Донецькій та Луганській областях.

відповідальність закладів вищої освіти обмежена обсягом державного фінансування $[17 ; 18 ; 19]$.

Серед значних зовнішніх факторів, що впливають на діяльність закладу фахової передищої освіти, основними є Болонський процес і офіційне приєднання до нього України, реформа освіти, що передбачена "Стратегією сталого розвитку “Україна - 2020”, ключовими векторами розвитку системи освіти, які закладені у Законах України "Про освіту", "Про вищу освіту”, "Про фахову передвищу освіту”, в “Концепції розвитку освіти України на період 2015 - 2025 рр."

У названих документах передбачені зміни в структурі освіти, перехід до конкурсного порядку розміщення державного замовлення на підготовку фахівців з вищою освітою, зміна умов вступу до закладів вищої освіти за рахунок розширення використання системи незалежного оцінювання знань (ЗНО), зниження кількості абітурієнтів тощо.

Внутрішнє середовище освітнього закладу надає сталий розвиток і безпосередній вплив на функціонування організації. Вивчення внутрішнього середовища спрямоване на 3'ясування того, якими сильними і слабкими сторонамиволодісорганізація. Дж. ПірсоміР.Робінсоном [23] було виділено набір ключових внутрішніх чинників, які можуть бути джерелом як сили, так і слабкості організації. Аналіз цих факторів, здійснений на основі SWOT-аналізу дає змогу коледжу скласти комплексне уявлення про внутрішнє і зовнішнє середовище організації і про iii слабкі та сильні сторони, можливості і загрози.

Для успішної діяльності на ринку освітніх послуг коледжу необхідно відстежувати і прогнозувати всі важливі для нього зміни зовнішнього і внутрішнього середовища. Своєчасно вжиті заходи дозволяють уникнути певних проблем і вигідно використовувати ситуацію, що склалася [18].
Зазначимо, що початок діяльності закладу фахової передвищої освіти виникає як відображення цілей і інтересів різних груп людей, так або інакше пов'язаних із діяльністю організації і зайнятих у процесі ії функціонування.

Для визначення рівня цього впливу використовується аналіз стейкхолдерів, або їх називають “учасниками коаліцій”. В цілому, поняття “стейкхолдер” означає будь-яку групу або індивіда, які можуть впливати на діяльність організації. Ньюбоулд і Луффман поділяють стейкхолдерів на чотири головні категорії [24]:

- групи впливу, що фінансують підприємство;

- менеджери, які керують ним;

- службовці, які працюють на підприємстві;

- економічні партнери.

Остання категорія включає як покупців і постачальників, так і інших економічних суб'єктів. Кожна 3 цих груп має різні параметри виміру діяльності, що впливає на формування стратегічних завдань. Інтереси стейкхолдерів визначають їх поведінку.

Тому під час формування місії, яка $\epsilon$ “вичерпним інструментом планування, який дозволяє менеджерам концентрувати увагу на основних напрямках сьогоднішньої і завтрашньої діяльності компаніі”' [7], необхідно відображати інтереси всіх їі стейкхолдерів.

Для вибору місії необхідно відповісти на два питання: "Хто наші клієнти?” та “Які потреби наших клієнтів ми можемо задовольнити?”

Науковець С. Виханский вважає, що найбільш стійкий, сильний і специфічний вплив на місію організації, незалежно від того, яка це організація, надають інтереси власників, працівників і покупців [2].

На основі визначеної місії формуються цілі закладу фахової передвищої освіти. Усі цілі повинні бути розумними, конкретними, вимірними, досяжними, співвіднесеними з ресурсами і 


\begin{tabular}{|l|l|}
\hline \multicolumn{1}{|l|}{ Компоненти безпосереднього оточення організації } \\
\hline Компоненти & Можливий спосіб аналізу \\
\hline Покупці & $\begin{array}{l}\text { Розробка стратегічного сегментування ринку, формування } \\
\text { профілю покупця }\end{array}$ \\
\hline Постачальники & Аналіз конкурентної сили постачальника \\
\hline Конкуренти & Оцінка “слабких" і “сильних" сторін конкурентів \\
\hline Ринок робочої сили & $\begin{array}{l}\text { Дослідження потенційних можливостей забезпечення } \\
\text { організації кадрами }\end{array}$ \\
\hline
\end{tabular}

обмеженими в часі. Відправним пунктом у процесі формулювання цілей $€$ вимірність завдання або обраний критерій ефективності [7].

Цілі діяльності, які ставляться на підприємствах сфери послуг і є основою для підготовки різноманітних планів, можуть класифікуватися за рівнем: стратегічні, тактичні, оперативні; часовим виміром: довгострокові, середньострокові, короткострокові; за сферами діяльності: технологічні, виробничі, маркетингові, економічні, соціальні, адміністративні, технологічні. Таким чином, цілі закладів фахової передвищої освіти мають якісний характер і $\epsilon$ складно вимірюваним. Стійкі конкурентні переваги закладу фахової передвищої освіти формуються переважно на основі нематеріальних стратегічних активів: висококваліфікованих кадрів, інформаційних ресурсів, знань і навичок. Такі активи не формуються одночасно, їх складно усунути або скопіювати конкурентам, однак нематеріальні активи вимагають і особливих механізмів їх збереження та примноження. У цьому і є особливість коледжу: результатом діяльності у закладі фахової передвищої освіти є i будуть якісні освітні послуги і дослідження, але не матеріальні блага [6].

Ключові рішення в галузі освітньої ідослідницької політики можуть прийматися в рамках чотирьох моделей управління закладом фахової передвищої освіти, серед них: колегіальна модель, ієрархічна модель, політична модель, анархічна модель [12; 16]. Сьогодні в закладах освіти переважають колегіальна і ієрархічна моделі [8].
Визначення цілей $є$ базою для переходу до наступного процесу стратегічного управління “вибору і виконання стратегії організації”.

Під стратегією при стратегічному управлінні ми розглядаємо напрям, шлях подальшої поведінки закладу освіти в ринковому середовищі, функціонування в рамках якої має привести організацію до досягнення поставлених перед нею цілей $[4 ; 8]$. У процесі розробки стратегії 3'являється можливість отримати відповіді на головні питання економіки “Що?”, “Як?” і “Для кого?"

За твердженням багатьох науковців, у т.ч. Дж. М. Еванса і Б. Бермана, стратегічне планування все тісніше пов'язується 3 маркетингом, і майбутнє, швидше за все, буде належати маркетингу.

Під час визначення цілей і завдань діяльності організації вирішальними стають вже його ринкові, а не виробничі можливості [10;20]. Таким чином, маркетинг відіграє ключову роль в процесі стратегічного планування, тому взаємозв'язок двох наук: менеджменту та маркетингу $е$ об'єктивним (табл. 3).

Цілі планування маркетингу і цілі діяльності організації у стратегічному управлінні повністю збігаються.

Як вважає один 3 провідних теоретиків і фахівців в галузі стратегічного управління М. Портер [18], до розробки стратегії поведінки організації на ринку існує три основні підходи: 1) Лідерство в мінімізації витрат виробництва. 2) Спеціалізація у виробництві продукції. 3) Фіксація

Взасмозв'язок менеджменту і маркетингу

\begin{tabular}{|l|l|}
\hline Процеси стратегічного управління & Маркетинговий процес \\
\hline аналіз середовища & аналіз маркетингових можливостей \\
\hline визначення місії та цілей & розробка маркетингових стратегій \\
\hline вибір стратегії & планування маркетингових програм \\
\hline виконання стратегії & управління маркетинговою діяльністю організації \\
\hline оцінка і контроль реалізації стратегії & контроль над ходом реалізації плану маркетингу \\
\hline
\end{tabular}




\section{СУЧАСНІ АСПЕКТИ РОЗВИТКУ КОЛЕДЖУ ЯК ЗАКЛАДУ ФАХОВОЇ ПЕРЕДВИЩОЇ ОСВІТИ}

певного сегмента ринку і концентрація зусиль фірми на обраному ринковому сегменті.

Найбільш поширені, вивірені практикою і широко проаналізовані в наукових джерелах $[4 ; 11$; 20] базисні стратегії розвитку бізнесу відображають чотири різних підходи до росту організації і пов'язані зі зміною стану одного або декількох елементів: продукту, ринку, галузі, положення фірми всередині галузі, технології.

Кожен 3 цих п'яти елементів може знаходитися в одному з двох станів: існуючий стан чи новий. Базисні стратегії можуть бути об'єднані в чотири основні групи, в кожній з яких вони підрозділяється на конкретні типи, які характеризуються певними особливостями.

Проведені дослідження довели, що існує кілька стратегій управління: максимальна якість, фінансові статки, диверсифікація, глобалізація, консервативна, стагнація, комбінована, максимальна якість.

На нашу думку, успішна розробка та реалізація вищевказаних стратегій у закладах фахової передвищої освіти багато в чому залежить від рівня розвитку системи управління, заснованої на засадах стратегічного менеджменту.

3 метою розв'язання стратегічних завдань, які ставить перед собою коледж, як заклад фахової передвищої освіти, важливо визначити основні цільові показники та систематизувати їх у вигляді плану.

Критеріями досягнення програмних цілей, можна вважати такі показники, як: рейтинг якості освітнього процесу, що необхідно визначати щорічно усіма учасниками освітнього процесу, індекс зростання рейтингу якості освітнього процесу; кількісні показники характеристик, що відрізняють властивості конкретних освітніх послуг від аналогічних послуг, що надаються конкурентами; кількісні відхилення від середнього, максимального і мінімального рівня цін на аналогічні послуги на ринку освітніх послуг.

Разом $з$ тим, необхідно зважувати і на інші критерії оцінки діяльності коледжу споживачами, такі як надійність, доступність, репутація, безпека, розуміння споживачів, чуйність, компетенція, ввічливість, комунікативність,

Усі зазначені показники є контролюючим параметрами діяльності закладу освіти, які дозволяють коригувати процес постановки і реалізації стратегічних цілей коледжу i забезпечити його розвиток і діяльність у відповідності до очікування споживачів та сприяти інноваційним підходам до ефективного управління розвитком коледжу.

Під час планування такої діяльності коледжу важливо враховувати, що на реалізацію місії та досягнення поставленої мети повинні бути спрямовані програмні ресурсні складові, що дозволяють охопити екстенсивні структурноорганізаційні та соціально-економічні напрями зростання коледжу відповідно до груп сформованих стратегій.

Висновок. Успішний розвиток і діяльність коледжу, як закладу фахової передвищої освіти, має пряму залежність від чітко сформованої місії, цілей та рівня розвитку системи управління, заснованої на засадах стратегічного менеджменту.

Для здійснення прийнятої місії і головної стратегічної мети коледжу необхідно створити відповідні умови для реалізації стратегічних цілей нижчого рівня, які є функціональними. Однією $з$ функціональних цілей є задоволення постійно зростаючих потреб в освітніх послугах, шляхом підвищення їхньої привабливості та конкурентоспроможності у порівнянні з основними конкурентами на географічних і демографічних ринках.

Підвищення якості і привабливість освітніх послуг можна досягти в результаті створення декількох стратегічних програм, що переслідуватимуть мету удосконалення системи забезпечення якості освітнього процесу на основі підвищення рівня кадрових, фінансових, матеріально-технічних та інформаційних ресурсів; удосконалити якість освітніх послугу у відповідності до реальних соціально-економічних умов розвитку країни та визначити критерії і показники досягнення програмних цілей.

Для того щоб система управління стратегічним розвитком коледжу була ефективною, вона повинна задовольняти цілому ряду вимог. Найбільш істотними вимогами $є$ система контролю.

\section{ЛIТЕРАТУРА}

1. Боумэн К. Основы стратегического менеджмента/Пер. сангл.Подред. Л.Г.Зайцева, М.И. Соколовой. Москва, 1997.

2. Виханский О.С., Наумов А.И. Менеджмент: учебник. 3-е изд. Москва,2003. 528 с.

3. Гевко О.Б., Шведа Н.М. Стратегічне управління: навчальний посібник. Для студентів усіх форм навчання напряму 6.030601 "Менеджмент”. Тернопіль, 2016. $152 \mathrm{c}$.

4. Деминг Э. Выход из кризиса: Новая парадигма управленя людьми системами и процесами. Пер с анг. Москва, 2007.370 с.

5. Закон України “Про фахову передвищу освіту". URL: https://zakon.rada.gov.ua/laws/main/2745-19

6. Ищук Т.Л. Особенности стратегического планирования в высшей школе. URL: https:// cyberleninka.ru. article > osobennosti-strategicheskogoplanirovani. 


\section{СУЧАСНІ АСПЕКТИ РОЗВИТКУ КОЛЕДЖУ ЯК ЗАКЛАДУ ФАХОВОЇ ПЕРЕДВИЩОЇ ОСВІТИ}

7. Каленюк I., Куклін О. Ризик - менеджмент у системі вищої освіти України. Вісник Київ. Нац. Ун-ту ім.Г.Шевченко. Економіка. Київ. 2015. Вип. 170. С. 2328. DOI: http://dx.doi.org/10.17721/1728-2667.2015/170-5/4

8. Клейнер Г. Б. Стратегия предприятия. URL: https:/ /institutiones.com/personalities/1038-kleyner-strategiyapredpriyatiya.html

9. Клименюк Н.Н., Безус А.Н. Доказательный менеджмент: введение в теорию. Монография. Киев, 2015. 272 c.

10. Клименюк М.M., Качарян I.C. Стратегія управління вищим навчальним закладом в сучасних умовах. Київ.2011. 192 с.

11. Котлер Ф., Келлер К.Л. Маркетиннг менеджмент. 12-е изд. Санкт Петербург, 2006. 816 с.

12. Лесечко М.Д., Рудницька Р.М. Стратегічне планування: навчальний посібник. Львів. 2004.76 с.

13. Лунячек В. Е. Педагогічний менеджмент: навчальний посібник. 2-е вид. випр. Харків, 2015. 512 с

14. Мескон М.Х, Альберт М., Хедоури Ф. Основь менеджмента: пер. с англ. Москва,1998. 704 с.

15. Натрошвілі С.Г. Стратегічне управління вищим навчальним закладом: теорія, методологія, практика Монографія. Київ, 2015. 326 с.

16. Пакулін С.Л. Стратегічне планування розвитку вищої освіти України: зміст, проблеми, пріоритети. URL: http://nbuv.gov.ua/UJRN/Pekon_2013_2_7

17. Ричард Л. Дафт Менеджмент. URL: http:// socioline.ru/pages/richard-1-daft-menedzhment

18. Старостіна А.О. та інші. Маркетинг: Навчальний посібник. 2-ге видання, перероб. і доп. Київ,2003. 326 с.

19. Томпсон А., Стрикленд А. Д. Стратегический менеджмент : пер. с англ. 12-е изд. Москва, 2003. 928 с.

20. Томпсон А.А., Стрикленд А.Дж. Стратегический менеджмент. Искуство разработки и реализации стратегии: Учебник для ВУЗов. Москва, 1998. 576 с.

21. Шаров O.I. МОН України: Фахова передвища освіта: нова місія. URL: https://rozmova.wordpress.com/ 2019/07/08/oleh-sharov-

22. Шершньова 3.Є., Оборська С.В. Стратегічне управління: Навч. посібник. Київ, 1999. 384 с.

23. Mintzberg H. The Rise and Fall of Strategic Planning $=$ Reconceiving Roles for Planning, Plans, Planners. USA : The Tree Press, 1994. $480 \mathrm{c}$.

24. Newbould G., Luffman G. Successful business politics. L., 1989

\section{REFERENCES}

1. Boumen,K. (1997). Osnovy strategicheskogo menedzhmenta [Fundamentals of Strategic Management]. Trans. from English. (Ed.). L.G. Zaytseva, M.I. Sokolova. Moscov. [in Russian].

2. Vikhanskiy, O.S. \& Naumov, A.I. (2003). Menedzhment: uchebnik [Management: textbook]. 3rd ed. Moscov, 528 p. [in Russian].

3. Hevko, O.B. \& Shveda, N.M. (2016). Stratehichne upravlinnia: navchalnyi posibnyk. Dlia studentiv usikh form navchannia napriamu 6.030601 "Menedzhment" [Strategic Management: A Tutorial. For students of all forms of study 6.030601 "Management]. Ternopil, 152 p. [in Ukrainian].
4. Deming, E. (2007). Vykhod iz krizisa: novaya paradigma upravlenya lyudmi sistemami i protsesami [Overcoming the crisis: A new paradigm of managing people systems and processes]. Trans. from English. Moscov, 370 p. [in Russian].

5. Zakon Ukrainy "Pro fakhovu peredvyshchu osvitu" [Law of Ukraine "On Professional Higher Education”]. Available at: https://zakon.rada.gov.ua/laws/main/2745-19 [in Ukrainian].

6. Ishchuk, T.L. Osobennosti strategicheskogo planirovaniya $\mathrm{v}$ vysshey shkole [The features of strategic planning in high school]. Available at: https:// cyberleninka.ru. article > osobennosti-strategicheskogoplanirovani. [in Russian].

7. Kaleniuk, I. \& Kuklin, O. (2015). Ryzyk menedzhment u systemi vyshchoi osvity Ukrainy [Risk Management in Higher Education in Ukraine]. Herald of Kyiv. National Taras Shevchenko University. Economy. Kyiv. Vol. 170.pp. 23-28. DOI: http://dx.doi.org/10.17721/ 1728-2667.2015/170-5/4[in Ukrainian]

8. Kleyner, G. B. Strategiya predpriyatiya [Enterprise strategy]. Available at: https://institutiones.com/ personalities/1038-kleyner-strategiya-predpriyatiya.html [in Russian].

9. Klimenyuk, N.N. \& Bezus, A.N. (2015). Dokazatelnyy menedzhment: vvedenie v teoriyu. Monografiya [Evidence-based management: an introduction to theory. Monograph]. Kiev, 272 p.[in Russian].

10. Klymeniuk, M.M. \& Kacharian, I.S. (2011). Stratehiia upravlinnia vyshchym navchalnym zakladom v suchasnykh umovakh [Strategy of managing the highest initial mortgage in ordinary minds]. Kyiv. 192 p. [in Ukrainian].

11. Kotler, F. \& Keller, K.L. (2006). Marketinng menedzhment.12-e izd. Marketing Management. The 12th ed.]. Sankt Peterburg, 816 p. [in Russian].

12. Lesechko, M.D. \& Rudnytska, R.M. (2004). Stratehichne planuvannia: navchalnyi posibnyk [Strategic Planning: A Tutorial]. Lviv. 76 p. [in Ukrainian].

13. Luniachek, V. E. (2015). Pedahohichnyi menedzhment : navchalnyi posibnyk. [Pedagogical Management: A Textbook]. Kharkiv, 512 p. [in Ukrainian].

14. Meskon, M.Kh, Albert, M. \& Khedouri, F. (1998). Osnovy menedzhmenta: per. s angl.[Fundamentals of Management: Trans. from English]. Moscov, 704 p. [in Russian].

15. Natroshvili, S.H. (2015). Stratehichne upravlinnia vyshchym navchalnym zakladom: teoriia, metodolohiia, praktyka [Strategic Management of Higher Education: theory, methodology, practice]. Monohraf. Kyiv. 326 p. [in Ukrainian].

16. Pakulin, S.L. Stratehichne planuvannia rozvytku vyshchoi osvity Ukrainy: zmist, problemy, priorytety [Strategic Planning for Higher Education in Ukraine: content, problems, priorities]. Available at: http:// nbuv.gov.ua/UJRN/Pekon_2013_2_7 [in Ukrainian]

17. Richard L. Daft Menedzhment [Management]. Available at: http://socioline.ru/pages/richard-1-daftmenedzhment [in Ukrainian].

18. Starostina, A.O.t et al. (2003). Marketynh: navchalnyi posibnyk [Marketing: Tutorial]. Kyiv, 326 p.[in Ukrainian]. 
19.Tompson, A. \& Striklend, A. D. (2003). Strategicheskiy menedzhment : per. s angl. 12-e izd. [Strategic Management: Trans. from English. 12th ed.]. Moscov, 928 p. [in Russian].

20.Tompson, A.A. \& Striklend, A.Dzh. (1998). Strategicheskiy menedzhment. Iskustvo razrabotki i realizatsii strategii: uchebnik dlya vuzov [Strategic management. The art of developing and implementing a strategy: a textbook for universities]. Moscov, 576p. [in Russian].

21.Sharo, O.I. MON Ukrainy: Fakhova peredvyshcha osvita: nova misiia [MES of Ukraine: Professional Higher Education: A New Mission]. Available at: https:// rozmova.wordpress.com/2019/07/08/oleh-sharov-[in Ukrainian].

22.Shershnova, Z.Ie. \& Oborska, S.V. (1999). Stratehichne upravlinnia: navch.posibnyk [Strategic Management: Tutorial]. Kyiv,384 p. [in Ukrainian].

23.Mintzberg, H. (1994). The Rise and Fall of Strategic Planning $=$ Reconceiving Roles for Planning, Plans, Planners. USA : The Tree Press, 480c. [in English].

24.Newbould, G. \& Luffman, G. (1989). Successful business politics. L. [in English].

Стаття надійшла до редакції 11.01.2020

УДК 37.015.3:159.964.2

DOI:

Євген Нелін, кандидат педагогічних наук, психоаналітик, освітній експерт

\section{ДІЯЛЬНІСТЬ БРУНО БЕТТЕЛЬХАЙМА І ПОПУЛЯРИЗАЦІЯ ПСИХОАНАЛІЗУ В ОСВІТНІЙ ПРАКТИЦІ}

У статті розкривається життєвий і творчий шлях Б. Беттельхайма, який був послідовником 3. Фрейда і розвивав ідеї психоаналізу в освіті. Досліджено особливості роботи Ортогенічної школи-клініки імені Соні Шенкман, яка діяла при Чиказькому університеті. Встановлено, що школа-клініка була закладом інтернатного типу, в якому шороку навчалися 50 дітей, які мали різні психічні розлади. Головна ідея школи полягала у створенні безпечного освітнього середовища для сочіалізаиії аутичних дітей.

Ключові слова: Б. Беттельхайм; психоаналітична педагогіка; дитина; інклюзивна освіта; виховання; психоаналіз; освітній процес.

Jim. 8.

Yevhen Nelin, Ph.D.(Pedagogy), Psychoanalyst, Educational Expert

\section{BRUNO BETTELHEIM'S ACTIVITIES AND THE POPULARIZATION OF PSYCHOANALYSIS IN EDUCATIONAL PRACTICE}

The article reveals the life and creative path of B. Bettelheim, who was a follower of Freud and developed the ideas of psychoanalysis in education. The peculiarities of the work of the Sonia Shankman Orthogenic School, which operated at the University of Chicago, were investigated. It was established that the school-clinic was a boarding school in which 50 children with various mental disorders were enrolled annually. The main idea of the school was to create a safe educational environment for the socialization of autistic children. Any manifestations of frustration and prohibitions were unacceptable at school, the responsibilities of children were not regulated, there were no assessments and homework. The pedagogical staff of the school-clinic consisted mainly of young graduates and psychologists, teachers and doctors. A key rule for educators in dealing with children was the utmost respect for the student's personality. Each tutor should be a role model and source of student support. In the educational work, one of the main techniques was to create a situation of success, which increased the efficiency of the educational process. The activities of the teachers of the school were aimed at helping children to normalize social interaction, to strengthen their self-awareness and to discover their talents. Often the child was given the opportunity to act as a teacher. The Sonia Shankman Orthogenic School works with many schools and universities.

After the death of Bruno Bettelheim, some of his colleagues and students criticized his teaching methods. They claimed that Bettelheim actually mocked the children and beat them. It is concluded that the identity of Bettelheim was one of the most controversial. His school was considered one of the most progressive on the planet. A similar school operated in the UK (Summerhill of Alexander Neill).

Keywords: B. Bettelheim; psychoanalytic pedagogy; a child; an inclusive education; an education; psychoanalysis; an educational process.

П остановка проблеми. Сучасна система освіти України проходить черговий етап реформ. При цьому, найбільше уваги приділяється середній освіті, зміни в якій відбуваються під прапором "Нової української школи”. На думку розробників концепції НУШ, вітчизняна система освіти має запозичити успішний досвід інших країн в аспектах демократизації освіти, популяризації педагогіки партнерства та інклюзивної освіти, 